\title{
実験棟における冬季の床下吸放熱特性の評価 空気式太陽熱集熱を利用した住宅のシステム性能改善に関する研究 その 1 EVALUATION OF THE CHARACTERISTIC OF HEAT FLOW UNDER THE FLOOR IN THE TEST BUILDINGS IN WINTER
}

A study on the improvement of system performance in the residential building using air-based solar heating system Part 1

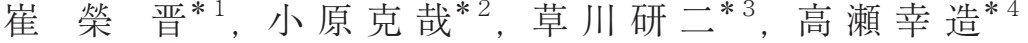 \\ 佐藤誠 ${ }^{* 5}$, 前 真 之*6, 盧 炫 佑*7, 駒野清治*8 \\ Youngjin CHOI, Katsuya OBARA, Kenji KUSAKAWA, \\ Kozo TAKASE, Makoto SATOH, Masayuki MAE, \\ Hyunwoo ROH and Seiji KOMANO
}

\begin{abstract}
For apprehending the performance of solar heating system, it is important to understand the relations of heating load and the system elements such as heat collection, heat storage, insulation, and so on. In this study, the measurements in the 3 buildings made progress at the same time for comparing the influence by these elements on the system, because the effect of the solar heating system is fluctuated by weather conditions. This paper describes outline of the measurements and specifications of the two test buildings that the air-based solar system is installed in. It also shows the changes of the heat flow on underground surface by installing the insulation under basement, changing the area of solar heat collector, or applying the water-pack as the additional heat storage.
\end{abstract}

Keywords : Air-based solar heating system, Heat balance, Heat flow on the ground surface 空気式太陽熱暖房，熱収支，基礎コンクリート吸放熱

\section{1. はじめに}

\section{1 背景と目的}

日本のエネルギー自給率は原子力を除くと $4 \%$ 程度と非常に低い 水準である。一方で、住宅の断熱基準は改善されてきているものの、 暖房の消費エネルギーは特に北陸以北では依然として大きい。2011 年の東日本大震災で被災した東北地方は冬の寒さが厳しく暖房の消 費エネルギーが大きいため、系統電源や化石エネルギーへの依存度 が低い自然エネルギーを活用した暖房が強く求められている。地熱、 風水力、潮力などの多様な自然エネルギーの研究が進んでいるが、 システムが単純・保守性に優れる・住戸単位でも使える利便性など の理由から太陽熱一の関心が高まっている。また、海外に目を向け てみると中国・韓国などでは太陽熱の給湯利用が盛んになっており、 今後は暖房への利用も進むことが予想される。
アクティブ式太陽熱利用には熱媒により大きく分けて液体式ある いは空気式集熱の 2 通りのシステムがある。集熱方式ごとの長所短 所があるが、水漏れの心配がないことや、集熱と同時に新鮮外気を 取り入れる換気を兼ねた暖房が可能であることから空気式集熱が注 目されており、本研究の対象システムとしている。

本報で扱う空気集熱式システムの集熱器は、屋根面の仕上げをそ のまま集熱面として利用する予備集熱器と高温集熱のためのガラス 集熱器（ガラス付き集熱器）で構成される。屋根裏のハンドリング ボックスのファンにより外気を取り入れて予備集熱器とガラス集熱 器で温めた空気は、床下を経て室内に流入した後、第 2 種換気とし て屋外に排気する。一般的な集熱器はシミュレーションによる年間 性能を把握しつつ、断熱材の劣化などの理由で夏の集熱空気温度の 上限が約 $80 \sim 100^{\circ} \mathrm{C}$ なるよう設計されている。ここで、冬期の室

\footnotetext{
*1 東京大学大学院工学系研究科建築学専攻 大学院生・修士 (工学)

*2 東京大学大学院工学系研究科建築学専攻 大学院生

*3 元 東京大学大学院工学系研究科建築学専攻 大学院生. 修士 (工学)

*4 東京大学大学院工学系研究科建築学専攻 特任研究員・博士 (工学)

*5 佐藤エネルギーリサーチ 代表取締役・博士(工学)

*6 東京大学大学院工学系研究科建築学専攻 准教授. 博士 (工学)

*7 OM ソーラー(侏) 取締役・技術部長・博士 (工学)

*8 OM ソーラー(株)技術部上席研究員
}

Graduate Student, Dept. of Architecture, the Univ. of Tokyo, M. Eng.

Graduate Student, Dept. of Architecture, the Univ. of Tokyo

Former Graduate Student, Dept. of Architecture, the Univ. of Tokyo, M. Eng.

Project Researcher, Dept. of Architecture, Graduate School of Eng., the Univ. of Tokyo, Ph. D.

Satoh Energy Research Co., Ltd., Ph. D.

Assoc. Prof., Dept. of Architecture, Graduate School of Eng., the Univ. of Tokyo, Ph. D.

Director, R\&D Department, OM Solar Inc., Ph. D.

Senior Researcher, R\&D Department, OM Solar Inc. 


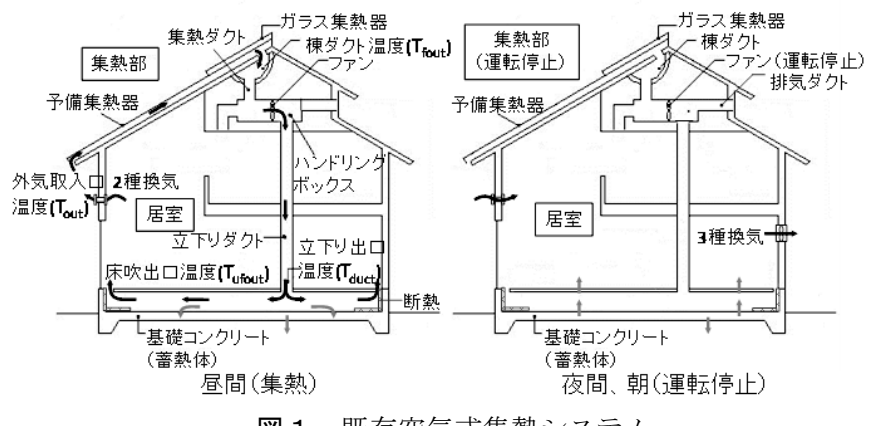

図 1 既存空気式集熱システム

内暖房負荷を賄うために必要な熱量、屋根面積、コストなどを考慮 した、予備集熱器とガラス集熱器の面積比、集熱風量に関する設計 法が必要である。また、昼間にのみ集熱可能であるという太陽熱利 用の特性上、集熱可能な時間帯と室内の暖房負荷発生時刻に差が生 じるので、太陽熱の有効利用のためには蓄熱が必要となる。空気集 熱の場合、空気の容積比熱が小さいため、容積比熱の大きい物質と 熱交換して蓄熱する必要がある。本システムでは、基礎床中心部を 蓄熱媒体として使用することを想定しており、基礎周りの断熱につ いては外気に面した基礎立ち上がり部と基礎床外周部に内断熱を設 置して熱損失低減を図る。既存の空気式集熱システムでは、図 1 の ように、昼間に集熱して温めた外気をハンドリングボックスから立 下りダクトを経由して床下空間に送ることで、床下の基礎コンクリ ートに蓄熱しつつ、床吹き出し口から居室に温風を供給する形式が 一般的である。しかし、これまで広く普及してきた空気式集熱シス テムは、外気に接する基礎立ち上がり部や地面に接する基礎コンク リート下面から熱損失が発生すること、基礎コンクリート表面での 吸放熱効率が低いことにより、昼間のオーバーヒート発生や夕方以 後の室温低下を抑制する効果が不十分であることが課題である。

空気式集熱システムの集熱部、蓄熱、放熱の性能に関してはこれ まで様々な研究が進められてきた。集熱部に関しては、田中ら ${ }^{1)}$ は 熱貫流率が異なるガラス種類、選択吸收膜有無、折板フィン有無な どによる 12 種類の異なる断面構造の屋根一体型空気式集熱器の性 能実験を行った。その結果、集熱器の構成により最大 $20 \%$ 以上の集 熱性能の違いを示した。

蓄熱・放熱に関しては、岩田ら 2)はシミュレーションで、冬期の 空気集熱暖房システムの基礎コンクリート床面の吸放熱量を計算し た。その結果、吸熱量の約 $12.5 \%$ が床下空間に放熱されるとした。 小金井ら ${ }^{3)}$ は太陽熱利用住宅における、長期実測調査をもとに年間 シミュレーションを行い、基礎コンクリートの厚さの変化、基礎下 断熱有無による基礎コンクリートの吸放熱特性を検討した。その結 果、断熱がない時はコンクリートの厚さが増すほど、基礎からの放 熱が少なくなり、基礎下断熱を適用することで、コンクリートへの 吸熱量は $4.5 \%$ 減少し、非集熱時の室内暖房に利用される熱量は $13 \%$ 上昇することから、暖房のためには基礎下断熱の必要性を示し た。しかし、これら研究では基礎表面の熱伝達率を固定值として計 算したため、シミュレーションの精度について追加検討の余地を残 しているとされている。赤嶺ら 4), 5)は、約 10 ケ月間の実測を通して、 基礎コンクリートの床面の月平均吸放熱量を求めた。吸熱量に対す る放熱量は、最大 $38.1 \%$ になった。これは地中への熱損失の影響と 考えられており、基礎下断熱の強化などによる熱損失を減らす検討
が必要である。宇田川ら ${ }^{6)}$ は床下に容積約 $6.5 \mathrm{~m}^{3}$ の砕石蓄熱を設置 し、冬期の代表日の温度、エネルギー使用量から太陽熱集熱や蓄熱 効果を測定した。浅野ら ${ }^{7)}$ は外断熱による断熱強化を行い、床下に 蓄熱ブロックの設置による蓄熱性能や室内暖房消費量を検討した。 その結果、1 日の集熱量に対する蓄熱量が約 38\%になった。これらの 結果から、蓄熱体の種類と容量や表面積、断熱性能、運転制御など の検討により、蓄熱体の吸放熱量を高めることができると考えられ る。基礎周りを扱った非定常伝熱シミュレーションで床下の吸放熱 を検討した先行研究があるが、システムと建物の詳細な実測に基づ いて、その精度を確認する必要がある。また、実住宅の実測による 床下の吸放熱量について検討した例があるが、日々変化する気象条 件に大きな影響を受ける太陽熱システムの改善前後を比較すること は容易ではない。そこで本研究では、静岡県浜松市内に異なる仕様 の 3 棟の実験棟を建設して、同じ環境条件で詳細測定を行い、建物 全体の総合的な熱収支を求め、集熱性能・蓄熱体での吸放熱性能の 改善案を示すことを目的とする。本報では、基礎の断熱仕様が異な る 2 棟の実験棟の詳細な比較をし、その結果から改善策の抽出を行 う。また、次報以降では実験結果をもとにシミュレーションの精度 検証を行った上で、対象建物・地域などの他条件での改善システム の性能を把握する。

\section{2 空気式集熱システムの熱収支計算法と改善ポイント}

空気式集熱システムの性能を決定する要素としては、集熱量、床 下蓄熱部の吸放熱量、居室の換気、貫流などによる熱損失などがあ る。集熱部の性能は、式 (1) に示寸集熱器の出口温度 $T_{\text {colout }}$ と入口 温度 $T_{o}$ の差と風量から求めた集熱量 $Q_{c o l}$ を用い、式（2）に示すよ うに、集熱器の傾斜面日射量と集熱量 $Q_{c o l}$ の比として瞬時集熱効率 $\eta$ で示される。このとき、空気の密度 $\rho$ は、大気圧 1 気圧 $(1013.25 \mathrm{hPa})$ とすると、式 (3) で与えられる。

$$
\begin{array}{ll}
Q_{\text {col }}=c \rho \cdot V \cdot\left(T_{\text {colout }}-T_{o}\right) & \cdots \cdot(1) \\
\eta=Q_{\text {col }} /\left(A_{\text {col }} \cdot I\right) & \cdots(2) \\
\rho=353.25 /\left(T_{\text {colout }}+237.15\right) & \cdots \cdot(3)
\end{array}
$$

また、集熱による室内暖房負荷への影響を確認するために式 (4) に示される室温基準集熱量 $Q_{r}$ を定義する。床下蓄熱体への吸熱量 $Q_{u f}$ は、式（5）のように、床下空間温度 $T_{u f}$ と蓄熱体表面温度 $T_{h s}$ の差、蓄熱体表面の対流熱伝達率 $\alpha_{c}$ から求める。

$$
\begin{aligned}
& Q_{r}=c \rho \cdot V \cdot\left(T_{\text {colout }}-T_{r}\right) \quad \cdots(4) \\
& Q_{u f}=\alpha_{c} \cdot\left(T_{u f}-T_{h s}\right) \cdot A_{h s} \\
& =F_{h s} \cdot A_{h s}
\end{aligned}
$$

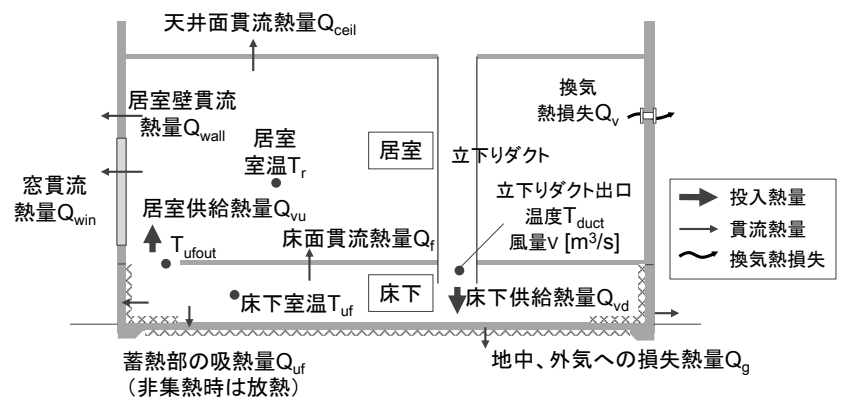

図 2 床下、居室の熱流量の定義 


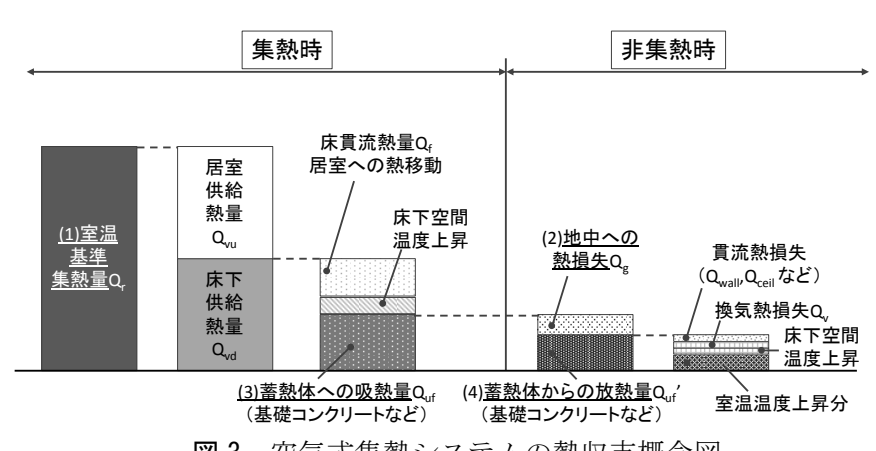

図 3 空気式集熱システムの熱収支概念図

（下線で示した部分が改善点）

図 2 のように、集熱器で加熱された空気は床下に移動して、基礎 コンクリートなどの蓄熱体に吸熱 $Q_{u \text { v }}$ 床面での熱伝導による居室 への熱移動 $Q_{f}$ が発生し、残った熱は床吹き出し口を通して室内居室 空間に移動する。これらの床下空間での熱収支は式（6）に示す。

$$
\begin{aligned}
Q_{v d} & =c \rho \cdot V \cdot\left(T_{\text {duct }}-T_{\text {ufout }}\right) \\
& =\left(c \rho \cdot V o I_{u f} \cdot \Delta T_{u f}\right)+Q_{f}+Q_{u f}
\end{aligned}
$$$$
\text { ・ ・ (6) }
$$

床吹き出しロからの集熱空気と床面からの貫流により、室内に流 入した熱は、室温の上昇と壁、天井、空などからの貫流熱損失 $\left(Q_{\text {wall }}\right.$ 、 $\left.Q_{c e i l} 、 Q_{w i n}\right) 、$ 換気による熱損失 $Q_{v}$ が発生する。室内の空からの日 射熱取得と内部発熱がない条件での居室熱収支は式（7）に示す。

$$
\begin{aligned}
Q_{v u}+Q_{f} & =c \rho \cdot V \cdot\left(T_{\text {ufout }}-T_{r}\right)+Q_{f} \\
& =\left(c \rho \cdot V_{1} \cdot \Delta T_{r}\right)+Q_{\text {wall }}+Q_{c e i l}+Q_{\text {win }}+Q_{V}
\end{aligned}
$$

ハンドリングボックスと立下りダクトまでの熱損失がないと仮定 すると、集熱器出口温度 $T_{\text {colout }}$ は、立下りダクト出口温度 $T_{\text {duct }}$ と同 じになって、式（8）のように、室温基準集熱量 $Q_{r}$ は、式（7）の 居室供給熱量 $Q_{v v}$ と式(6)の床下供給熱量 $Q_{v d}$ の合計と同じになる。 以上の熱収支を総合すると、図 3 のようになる。

$$
Q_{v u}+Q_{v d}=c \rho \cdot V \cdot\left(T_{d u c t}-T_{r}\right)=Q_{r}
$$

図 3 のように、非集熱時の暖房負荷削減のためには、以下の検討 が必要となる。

（1）室温基準集熱量の増加：集熱面積の増加及びガラス集熱器 の性能改善など

（2）地中への熱損失の減少：基礎下断熱設置など

（3）蓄熱体一の吸熱量増加：付加蓄熱体設置など

（4）蓄熱体からの放熱量の増加：蓄熱体の表面積増加や夜間、 朝の室内循環制御

本研究では、図 4 のように、(1)ガラス集熱器の集熱面（ガラス種 類による日射取得率向上や熱損失率低減）の性能向上によって集熱 効率を改善し、太陽熱だけではなく太陽光発電のための PV パネル を予備集熱器に設置し、太陽エネルギーの利用効果を高めることを 意図している。PV パネルは既存の予備集熱器と同等以上の集熱性 能があり、空気式太陽熱集熱の予備集熱器として十分に利用できる。 また、(2)集熱時の基礎立ち上がり部貫流熱量を最小限に抑えるため に断熱方法や断熱材厚さ等を検討し、蓄熱体に吸熱された熱の外気 や地中への損失量の低減を検討する。本報では、基礎下断熱の有無 による建物全体の熱収支を把握し、次報ではシミュレーション等に
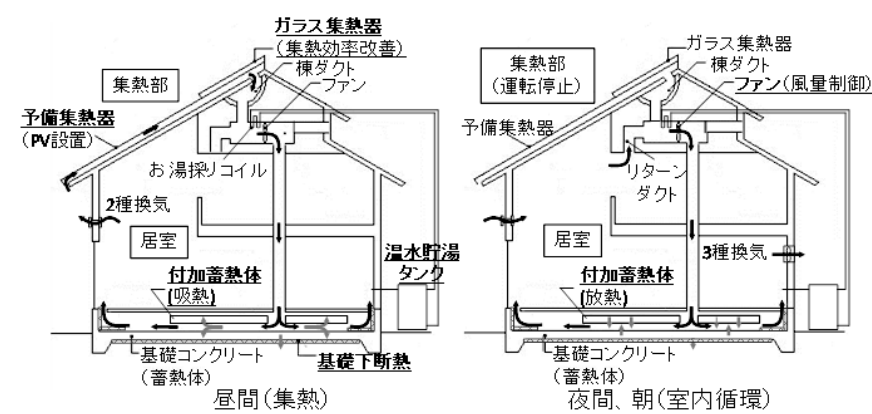

図 4 本研究のシステム改善案（下線で示した部分が改善案）

より、より効果的な断熱仕様を検討することとする。また、(3)の、 蓄熱体への吸熱量の増加については、床下空間に付加蓄熱体として 水パックを設置し、床下での熱容量を増加させる。(4)の、蓄熱体か らの放熱量の増加については、非集熱時にハンドリングボックスの ファン運転により床下と居室の空気を室内循環させることが可能で あるが、この送風によって蓄熱体となる基礎や付加蓄熱体からの対 流熱伝達を促進し放熱量を増加させて夜間の室温低下を防ぐ。さら に、夏・中間期などの暖房を必要としない場合、集熱した空気と八 ンドリングボックスに内蔵されたお湯取りコイルを通る液体熱媒と の熱交換を行うことで、貯湯タンクに蓄熱して給湯用途にも利用で きることから、実験・シミュレーションにより給湯負荷削減効果に ついても評価を行う。本稿では、システム改善の基礎研究として、 実験棟における冬期実験データをもとに基礎下断熱の設置、集熱量 の変化、付加蓄熱体（水パック）の有無による床下空間の熱収支の 変化を検討する。その上で、非集熱時の居室暖房負荷低減に対して 重要となる蓄熱部位での吸放熱量の増加方策に対する知見を得る。

\section{2. 実験棟の概要}

\section{1 建物概要}

本研究で解析対象としている実験棟は 2012 年 3 月に静岡県浜松 市に 3 棟、同じ規模のものが建設された。実験棟の写真を図 5 に示 す。内部は図 6 のように、居室、床下空間、小屋裏、計測器室の 4 室で構成される。実験棟の断熱材は住宅性能表示基準の等級 4 に相 当する厚さとした（表 1 ）。いずれも主開口が真南に向くよう配置さ れており、実験棟の延床面積は $33.12 \mathrm{~m}^{2}$ で、暖房対象室の居室は約 $23 \mathrm{~m}^{2}$ である。実験棟(1)は基礎下の断熱材を施工せず、熱損失係数 $\mathrm{Q}$ 值（実測值 (測定方法は、文献8を参照) は $3.4 \mathrm{~W} / \mathrm{m}^{2} \mathrm{~K}$ であった。実験棟(2) と

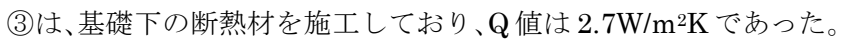
なお今回の $\mathrm{Q}$ 值測定では、床下空間を積極的に加熱するという暖房 方式の評価のため、居室の床板を取り外して居室と床下空間を一室 として測定した。

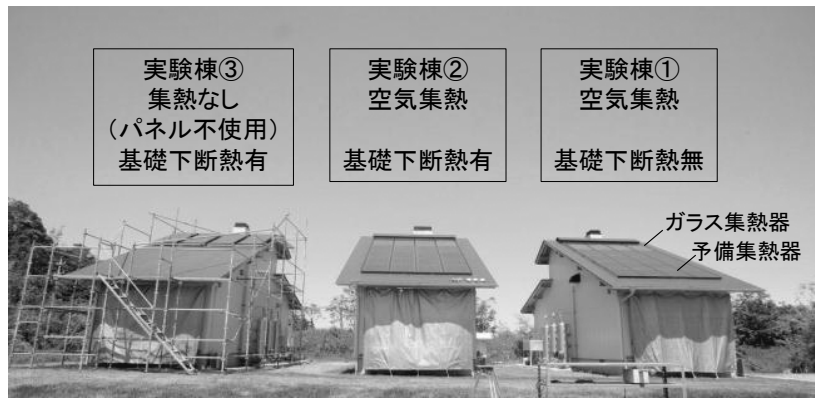

図 5 実験棟の概観 
表 1 実験棟の仕様

\begin{tabular}{|c|c|}
\hline \multirow{2}{*}{ 基礎コンクリート } & 立ち上がり：幅 $150 \mathrm{~mm}$ * 高さ $600 \mathrm{~mm}$ \\
\hline & 平面：厚さ $180 \mathrm{~mm}^{*}$ 幅 $3790 \mathrm{~mm}^{*}$ 長さ $6520 \mathrm{~mm}$ \\
\hline (U 值 : $\left.0.335 \mathrm{~W} / \mathrm{m}^{2} \mathrm{~K}\right)$ & $\begin{array}{l}\text { カラー鋼板, } \mathrm{PB} \mathrm{t}=9.5 \mathrm{~mm} \text {, 通気層 } \mathrm{t}=36 \mathrm{~mm} \text {, } \\
\text { 透湿防水シート, 構造用合板 } \mathrm{t}=9 \mathrm{~mm}, \\
\text { 高性能 } \mathrm{GW} 16 \mathrm{~K} 100 \mathrm{~mm}, \mathrm{~PB} \mathrm{t}=12.5 \mathrm{~mm}\end{array}$ \\
\hline 床 & 構造用合板 $28 \mathrm{~mm} \quad$ (熱伝導率 : $0.13 \mathrm{~W} / \mathrm{mK})$ \\
\hline $\begin{array}{c}\text { 天井 } \\
\left(\mathrm{U} \text { 值 : } 0.361 \mathrm{~W} / \mathrm{m}^{2} \mathrm{~K}\right) \\
\end{array}$ & $\begin{array}{l}\text { 構造用合板 } \mathrm{t}=28 \mathrm{~mm}, \text { フェノールフォーム } \\
\mathrm{t}=80 \mathrm{~mm} \text {, 空気層 } 40 \mathrm{~mm}, \mathrm{~PB} \mathrm{t}=9.5 \mathrm{~mm}\end{array}$ \\
\hline $\begin{array}{c}\text { 屋根 } \\
\left(\mathrm{U} \text { 值 : } 0.627 \mathrm{~W} / \mathrm{m}^{2} \mathrm{~K}\right) \\
\end{array}$ & $\begin{array}{l}\text { 樹脂系ルーフィング } \mathrm{t}=0.42 \mathrm{~mm}, \\
\text { 構造用合板 } \mathrm{t}=12 \mathrm{~mm}, \mathrm{GW} 32 \mathrm{~K} \mathrm{t}=50 \mathrm{~mm}\end{array}$ \\
\hline $\begin{array}{c}\text { 南面・北面空 } \\
\text { 南は全面日射遮蔽有 } \\
\end{array}$ & $\begin{array}{l}\text { Low-E（断熱） ガラス }\left(3-\mathrm{A} 12-3 、 \mathrm{U} \text { 值 : } 1.7 \mathrm{~W} / \mathrm{m}^{2} \mathrm{~K}\right) \\
+ \text { アルミ複層障子・樹脂複合枠(下枠二重断熱) }\end{array}$ \\
\hline 基礎下断熱 & $\begin{array}{l}\text { 押出法 XPS } 3 \text { 種 } \mathrm{B} \mathrm{t}=50 \mathrm{~mm} \quad \text { (実験棟(2),(3)のみ) } \\
\text { (熱伝導率 }: 0.03 \mathrm{~W} / \mathrm{mK})\end{array}$ \\
\hline \multirow{2}{*}{ 基礎断熱 } & 立ち上がり：押出法 XPS 3 種 $\mathrm{B} \mathrm{t}=50 \mathrm{~mm}$ \\
\hline & 外周部：押出法 XPS 3 種 B t=50mm(幅 : $700 \mathrm{~mm}$ ) \\
\hline $\begin{array}{l}\text { 居室と計測器室の } \\
\text { 仕切り扉 }\end{array}$ & $\begin{array}{l}\text { シナベニア } \mathrm{t}=3 \mathrm{~mm}, \mathrm{GW} 32 \mathrm{~K} \mathrm{t}=25 \mathrm{~mm}, \\
\text { シナベニア } \mathrm{t}=3 \mathrm{~mm}\end{array}$ \\
\hline
\end{tabular}

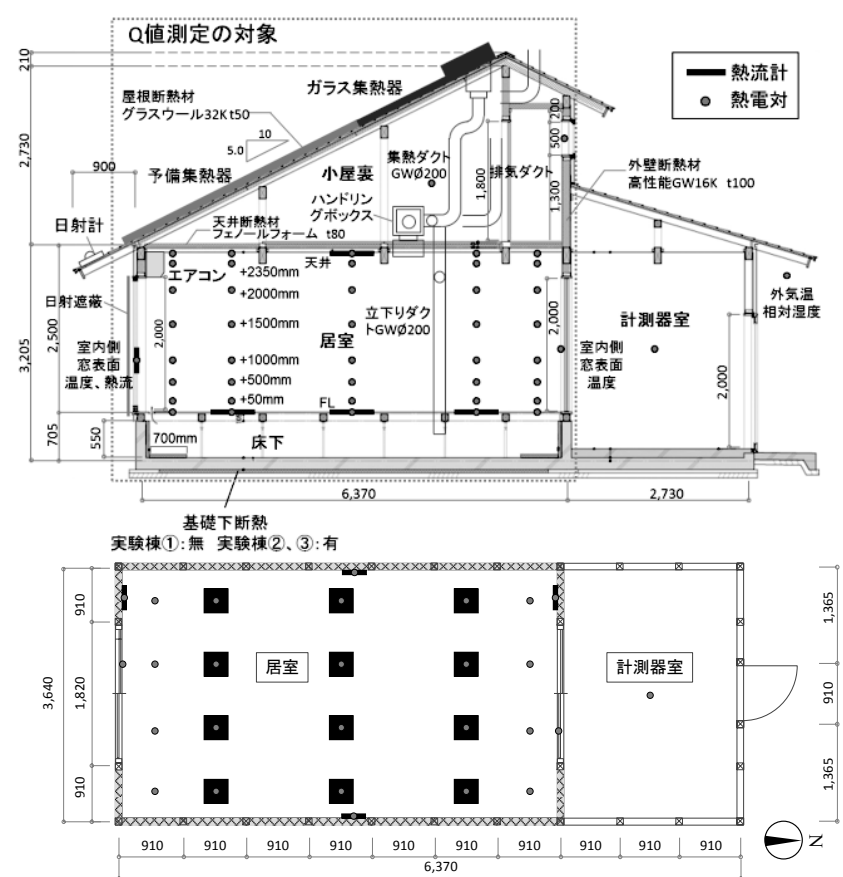

図 6 実験棟の断面図、平面図、測定点

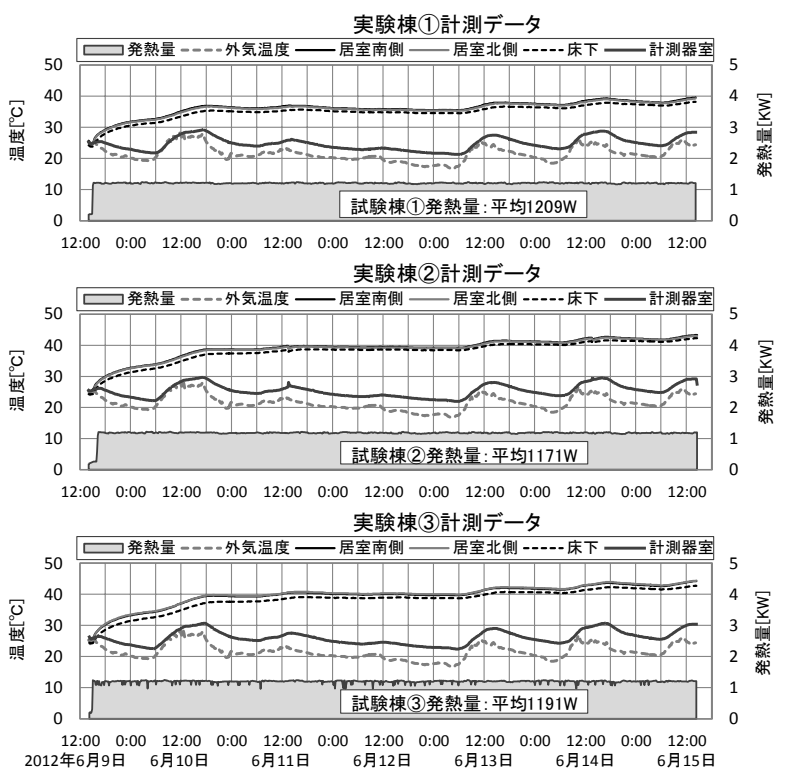

図 7 Q 值測定時の室温変動とヒーター発熱量

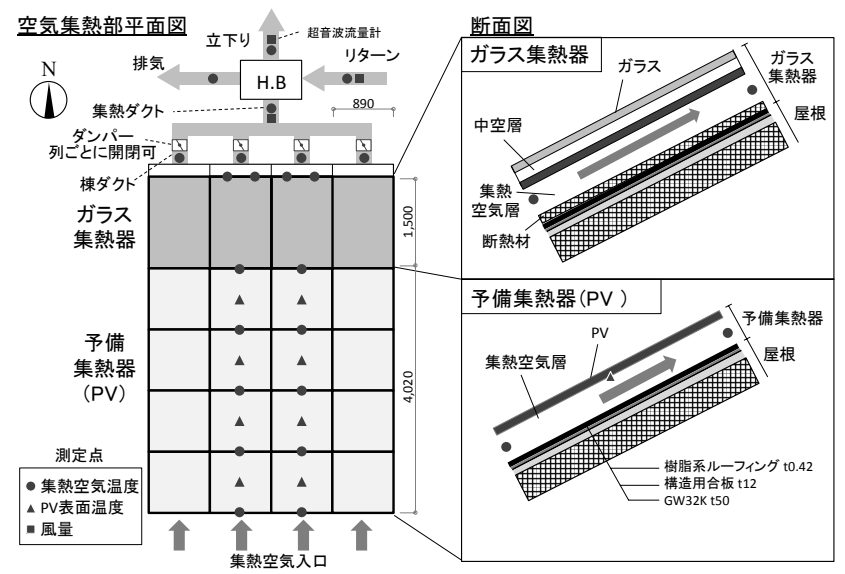

図 8 実験時に使用した空気式集熱器と測定点

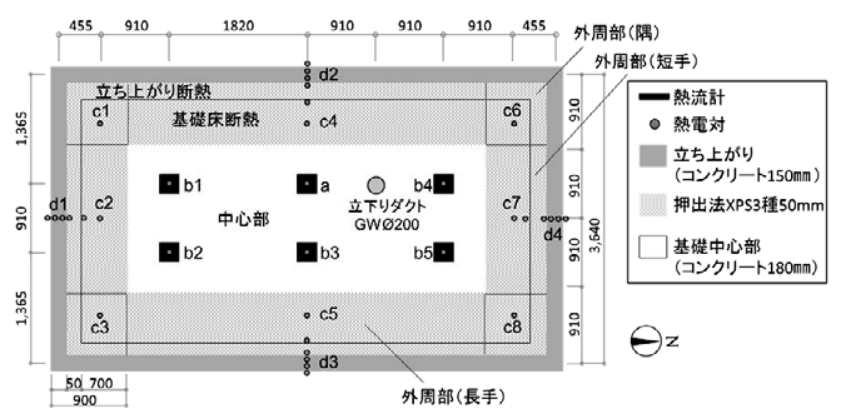

(1)実験棟 (1)、(2)、(3)床下平面図

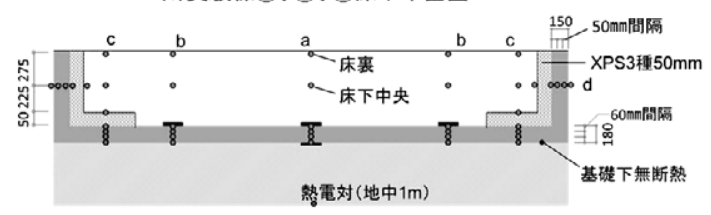

(2)実験棟(1)床下断面図

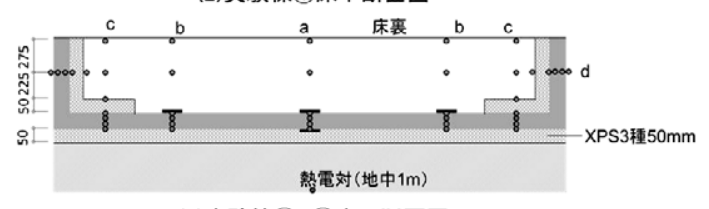

(3)実験棟(2)、(3)床下断面図

図 9 床下温度、熱流の測定位置

また、開口部に遮熱シートを設置して日射熱収得を遮断して内部を ヒーターで加熱しており、サーキュレーターで摚挥することで室内 温度分布を均一化した。図 7 に Q 值測定時の室温変動とヒーター発 熱量を示す。 $\mathrm{Q}$ 值の影響で、同発熱量で実験棟(1)の居室温度は他の 実験棟の居室温度より低く推移した。集熱器は図 8 のように横方向 に 4 列設置され、各列に設置されたダンパーの開閉で集熱面積を調

表 2 太陽光発電システムの仕様

\begin{tabular}{|c|c|c|c|}
\hline & & 実験棟(1) & 実験棟(2) \\
\hline \multirow{4}{*}{$\begin{array}{c}\text { 太陽光発電 } \\
(\mathrm{PV}) \\
\text { パネル }\end{array}$} & \multirow{2}{*}{$\begin{array}{c}\text { モジュール定格 } \\
\text { 発電効率 }\end{array}$} & $12.8 \%$ & $11.4 \%$ \\
\hline & & \multicolumn{2}{|c|}{ (PVパネル温度補正係数: $\left.-0.37 \% /{ }^{\circ} \mathrm{C}\right)$} \\
\hline & $\begin{array}{c}\text { パネル全体の } \\
\text { 定格出力 }\end{array}$ & $1792 \mathrm{~W}$ & $1600 \mathrm{~W}$ \\
\hline & 外形寸法 & \multicolumn{2}{|c|}{$\begin{array}{c}\mathrm{W} 3560 \mathrm{~mm} \cdot \mathrm{D} 3920 \mathrm{~mm} \cdot \mathrm{H} 35 \mathrm{~mm} \\
\text { / パネル全体 } \\
\mathrm{W} 890 \mathrm{~mm} \cdot \mathrm{D} 980 \mathrm{~mm} \cdot \mathrm{H} 35 \mathrm{~mm} \\
\text { / モジュール }\end{array}$} \\
\hline $\begin{array}{c}\text { パワーコンデ } \\
\text { イショナ } \\
\end{array}$ & $\begin{array}{c}\text { 定格変換効率 } \\
\text { (JIS C } 9861 \text { 準拠) } \\
\end{array}$ & \multicolumn{2}{|c|}{$94.5 \%$} \\
\hline \multicolumn{2}{|c|}{ システム定格効率 } & $12.1 \%$ & $10.8 \%$ \\
\hline
\end{tabular}


節可能である。実験棟(1)の予備集熱器には 1 モジュール $0.87 \mathrm{~m}^{2}$ あ たりの定格発電量 $112 \mathrm{~W}$ の PV パネルを、実験棟(2)の予備集熱器に は 1 モジュール $0.87 \mathrm{~m}^{2}$ あたりの定格発電量 $100 \mathrm{~W}$ の PV パネルを 設置した。太陽光発電システムの仕様を表 2 に示す。空気式集熱器 は実験棟(1)と(2)のみ設置し、1列あたりの面積は、予備集熱器（PV

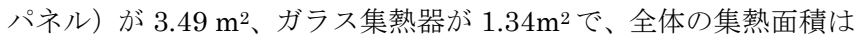
予備集熱器 $13.96 \mathrm{~m}^{2}$ 、ガラス集熱器 $5.34 \mathrm{~m}^{2}$ である。なお、本実験 では太陽熱集熱の効果を明確にするため、空の外側に日射遮蔽シー トを設置して南空からの日射熱取得がないようにした。

\section{2 測定概要}

集熱部や基礎周りでの蓄熱の状況を詳細に測定するために外部気 象（温湿度、水平面・集熱屋根面の全天日射量、風向風速など）、居 室室温だけでなく、床下空間の基礎表面、居室の床・壁・天井・ガ ラス面の熱流計を多数設置した。基礎床外周部は熱流計を設置して いなかったため、基礎床外周部の熱流は断熱材の上下に設置した熱 電対による上下温度差と断熱材の熱抵抗から定常熱伝導を仮定して 求めた。なお、断熱材の熱容量は小さいことから、吸放熱時の断熱 材への蓄熱の影響については、今回は無視している。計測項目の詳 細は付表 2 に示す。 4 列の各集熱器の出入口温度、集熱空気層の温 度データと傾斜面日射量、集熱風量データから集熱面積変化による 集熱パネル内部温度分布や集熱量、集熱効率の比較をより正確に検 討することが可能である。特に空気式集熱システムに重要となる、 基礎への蓄熱や地中への熱損失など床下空間での熱バランスを評価 することを意図している。すべての測定は 1 分間隔で行った。床下 の温度、表面熱流の計測位置は図 9 に示す。

\section{3 実験概要}

空気式集熱システムの場合、床下空間の基礎コンクリートを蓄熱 体に利用するため、床下の基礎まわりの断熱状況によって基䃈への 吸放熱性状は大きく変わると考えられる。基礎コンクリートを蓄熱 体として用いた空気式集熱システムでは、基礎コンクリートと地中 間の熱移動による地中温度変化が生じる。その結果、地中温度は基 礎コンクリートと床下空気間の吸放熱量に影響を与える。本来、数 年間の長期実測による地中温度変化及び基礎コンクリートの吸放熱 量変化を検討寸る必要があると考えられるが、本実験では 1 シーズ ンの中で基䃈下断熱設置有無や床下空間の熱容量増加などの条件に おいて空気式集熱システムの改善可能性を検討するために、1 週間 程度ずつの短期実験による評価を行うこととした。なお、小金井ら 3)の基礎コンクリート断熱有無による吸放熱量の変化に関するシミ ユレーションの結果と同様の傾向が、後述する今回の短期実測によ っても確認されたために実験結果には妥当性があるものと判断し、

表 3 実験条件

\begin{tabular}{|c|c|c|c|c|c|}
\hline & \multicolumn{2}{|c|}{ 集熱面積 $\left[\mathrm{m}^{2}\right]$} & \multirow{2}{*}{$\begin{array}{c}\text { 設定風量 } \\
{\left[\mathrm{m}^{3} / \mathrm{h}\right]}\end{array}$} & \multirow{2}{*}{ 蓄熱体 } & \multirow{2}{*}{ 測定期間 } \\
\hline & 予備集熱 & ガラス & & & \\
\hline 実験 A & \multicolumn{2}{|c|}{$\begin{array}{l}\text { 無（ヒーターに } \\
\text { よる加熱実験） }\end{array}$} & 250 & 基礎 & $\begin{array}{c}\text { - 加熱実験 : } 2012 \text { 年 } 11 \text { 月 } 28 \text { 日 } \\
\sim 12 \text { 月 } 10 \text { 日 } 17 \text { 時 } 30 \text { 分 } \\
\text { - 停止期間 : } \sim 12 \text { 月 } 13 \text { 日 } 24 \text { 時 }\end{array}$ \\
\hline 実験 B & 7.0 & 2.7 & 120 & 基礎 & $\begin{array}{l}2012 \text { 年 } 12 \text { 月 } 29 \text { 日 } \\
\sim 2013 \text { 年 } 1 \text { 月 } 6 \text { 日 }\end{array}$ \\
\hline 実験 C & 14.0 & 5.3 & 240 & 基礎 & 2013 年 1 月 7 日 14 日 \\
\hline 実験 D & 14.0 & 5.3 & 240 & $\begin{array}{c}\text { 基礎 } \\
\text { +水パック }\end{array}$ & 2013 年 1 月 24 日 29 日 \\
\hline
\end{tabular}

一連の実験結果の分析を行っている。さらに次報では、床下空間の 熱移動に関するモデル化を行った熱回路網計算を用いて実験結果と の精度検証を行ったうえで長期間での運用を考慮した評価を行い、 システム性能改善効果に関するより詳細な分析を行うこととする。 本実験では、3つの棟で同時測定したデータの解析が可能である が、本報では、空気式集熱システムを実装した実験棟(1)、(2)の 2 棟 を対象とした。まず、ヒーターを用いて床下空間を加熱する実験を 行い、基礎下の断熱材の有無による床下空間の蓄熱効果と熱損失量 を比較した。次に、実際の屋外気条件下で、集熱器面積の違いによ る基礎の各部位別の吸熱・放熱量とエアコン消費電力の変化を比較 した。さらに、床下空間の熱容量を増加させるため、水入りパック を床下に設置した際の吸熱・放熱量についても検討した。基礎コン クリートに蓄熱された熱は外気や地中へのロスが生じるが、水パッ クに蓄熱された熱はすべて床下空間に放熱するので、ロスが少なく なるという長所がある。表 3 に実験条件を示す。
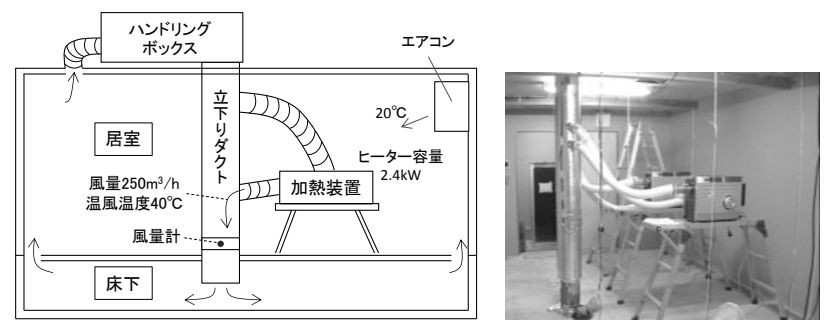

図 10 加熱装置の設置状況

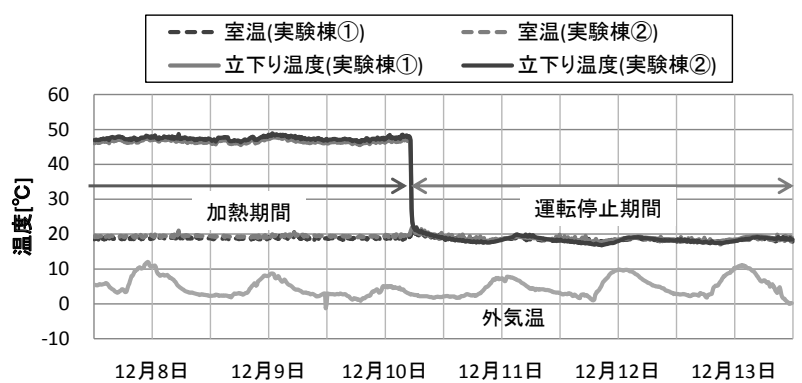

図 11 加熱実験時、運転停止時の立下りダクト内空気温、 居室室温と外気温

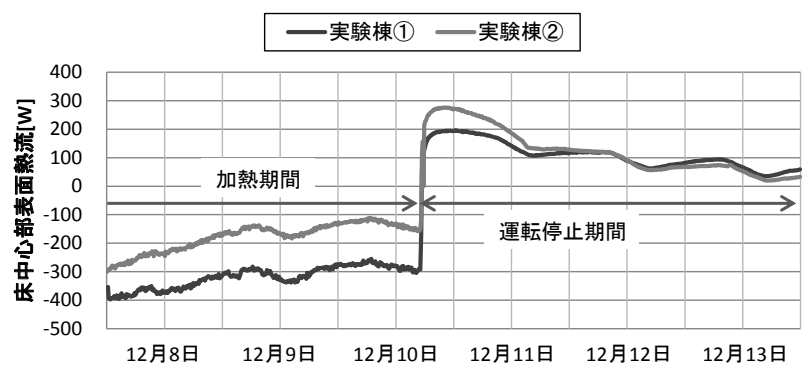

図 12 基礎床中心部の吸放熱量

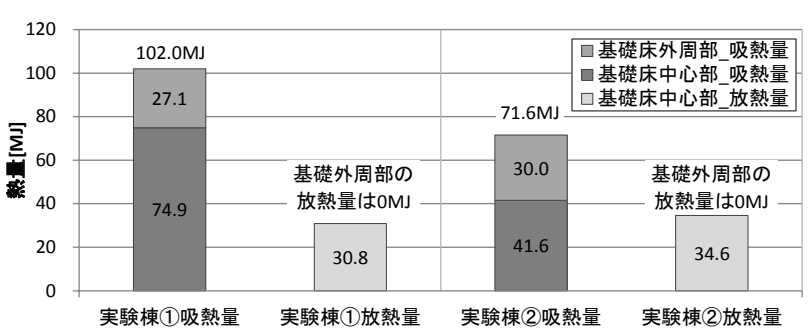

図 13 基礎床中心部の吸放熱期間積算 


\section{3. 実験結果}

\section{1 実験 A の結果（ヒーターによる床下加熱実験）}

まず、予備検討として、気象状況に関わらず同一の熱量を供給可 能な加熱装置（ヒーター最大容量 $2.4 \mathrm{~kW}$ ）を図 10 のように実験棟 (1)と (2)の床下空間に繫がっている立下りダクトに設置し、基礎下断 熱の有無による吸放熱量の違いを把握した。加熱装置は温風温度 $40^{\circ} \mathrm{C}$ 、風量約 $250 \mathrm{~m}^{3} / \mathrm{h}$ と設定し、室温はエアコン運転することで実 験期間中は $20^{\circ} \mathrm{C}$ で一定となるようにした。ヒーターによる加熱は 2012 年 11 月 28 日から 12 月 10 日 17 時 30 分まで行い、以降は基 礎コンクリートの放熱状況を検討するため 12 月 13 日 24 時まで停 止した際のデータを取得した。ここでは、12月 8 日から 12 月 13 日の測定結果を示す。図 11 に実験期間の居室室温と外気温の変化 を示す。図 12 には実験棟(1)と (2)の基礎床中心部に設置した 6 つの 熱流計(図 9 の a, b1〜b5)の結果に基礎床中心部を 6 等分した面積を 乗じた吸放熱量を示す。図 13 の結果のように基礎下断熱がない実
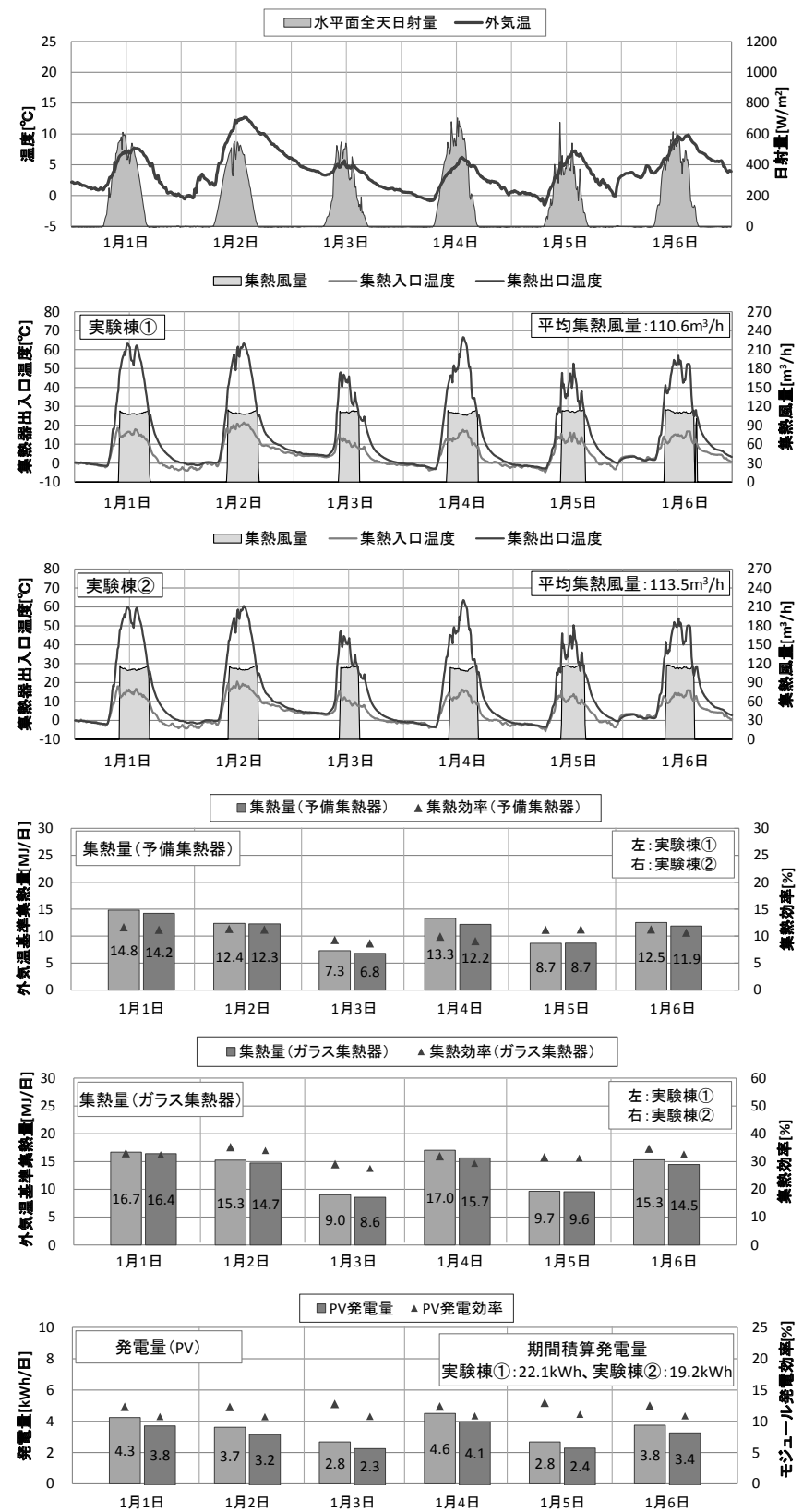

図 14 気象状況、集熱・PV 発電結果(1月 1 日 6 日)
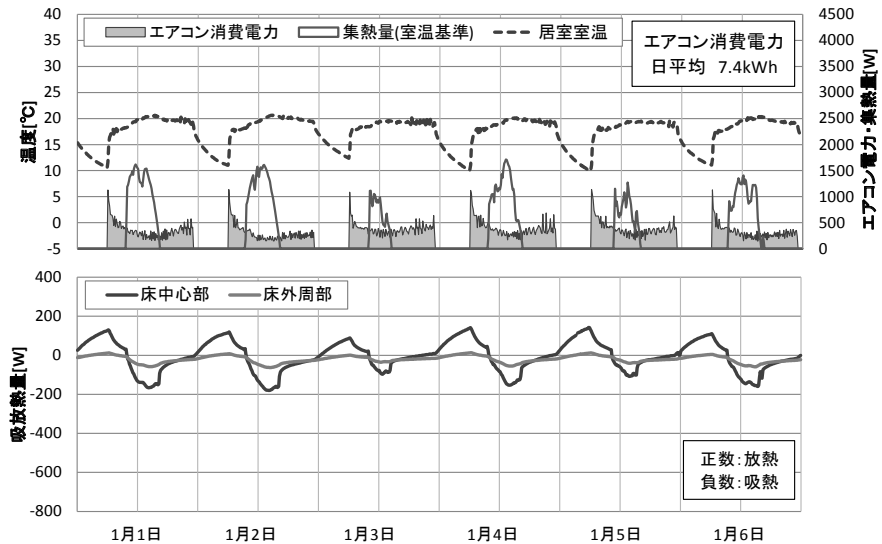

図 15 実験棟(1)の室温、集熱量、エアコン消費電力、基礎吸放熱

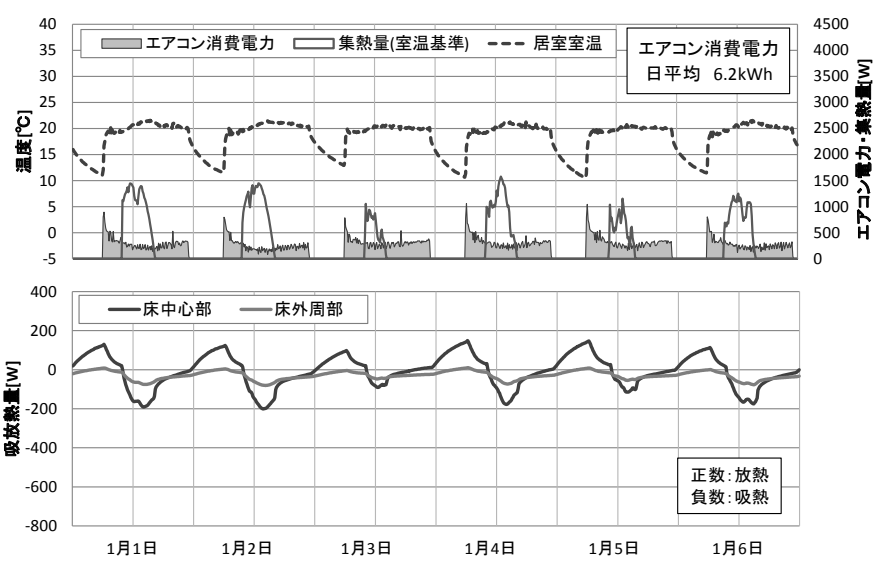

図 16 実験棟(2)の室温、集熱量、エアコン消費電力、基礎吸放熱 験棟(1)の吸熱量(102.0MJ)は断熱ありの実験棟(2)の吸熱量(71.6MJ) より約 42.5\%多いが、放熱量は実験棟(1)の方(30.8MJ)が実験棟(2) (34.6MJ)より約 $12 \%$ 少ないという結果になった。この結果は、基礎 下断熱がないと集熱時に地中でも蓄熱を行うため、基礎コンクリー トの温度が低い温度で推移して吸熱量が増えるとともに、加熱停止 後も基礎コンクリートから地中への熱流があるため、床下空間への 放熱量が減ることになるといえる。

\section{2 実験 B の結果（集熱 2 列でのシステム運用状況）}

実験棟(1)、(2)で実際に空気式集熱システムを使用して、基礎コン クリートの下の断熱材有無による集熱時の吸放熱量の変化と、それ によるエアコン暖房による消費エネルギーの変化を比較した。実験 期間は 2012 年 12 月 29 日から 2013 年 1 月 6 日まで 9 日間行った。

表 4 エアコン仕様と運転条件

\begin{tabular}{c|c|c}
\hline \multirow{2}{*}{ エアコン仕様 } & 暖房定格能力 & $2.8 \mathrm{~kW}$ \\
\cline { 2 - 3 } & 暖房定格消費電力 & $565 \mathrm{~W}$ \\
\hline \multirow{2}{*}{ 運転条件 } & 運転時間 (タイマー運転 $)$ & $06: 00 \sim 23: 00$ \\
\cline { 2 - 3 } & 設定室温 & $20^{\circ} \mathrm{C}$ \\
\hline
\end{tabular}

表 $5 \mathrm{PV}$ 発電効率（1月 1 日 6 日）

\begin{tabular}{c|c|c}
\hline & 実験棟1 & 実験棟(2) \\
\hline モジュール発電効率実験結果 & $12.6 \%$ & $10.9 \%$ \\
(定格モジールル発電効率) & $(12.8 \%)$ & $(11.4 \%)$ \\
\hline パワーコンディショナナ変換効率実験結果 & $92.5 \%$ & $95.9 \%$ \\
(定格パワーコンディショナナ変換効率) & $(94.5 \%)$ & $(94.5 \%)$ \\
\hline
\end{tabular}


エアコンの仕様と運転条件を表 4 に示す。ここでは、比較的日射量 が安定していた 2013 年 1 月 1 日〜 月 6 日の計測結果を対象とし て分析を進める。集熱面積は、4 列のうち中央 2 列（予備集熱面積 $7.4 \mathrm{~m}^{2}$ 、ガラス有効集熱面積 $\left.2.5 \mathrm{~m}^{2}\right)$ のみ使用し、図 14 のように、 風量は約 $110 \mathrm{~m}^{3} / \mathrm{h}$ で集熱運転を行った。

実験期間の外気温、水平面日射量、集熱状況を図 14 に示す。 6 日 間の外気温基準の集熱量合計は実験棟(1)が $160.6 \mathrm{MJ}$ (平均集熱風量 $110.6 \mathrm{~m}^{3} / \mathrm{h}$ )、実験棟(2)が $146.2 \mathrm{MJ}$ （平均集熱風量 $113.5 \mathrm{~m}^{3} / \mathrm{h}$ ) で約 9.0\%の差があるが、これは施工精度や薄い集熱空気層内での温度測 定位置のわずかなずれが影響している可能性があり、今後の検討を 要する。PV 発電効率は、表 5 のように定格システム効率と実験值 の大きな差はなかった。実験棟同士の集熱量の差については基礎コ ンクリートの吸放熱の比率に関する今回の実験では影響が少ないも のと判断し、以降の検討を進めた。図 15,16 に基礎下断熱有無によ
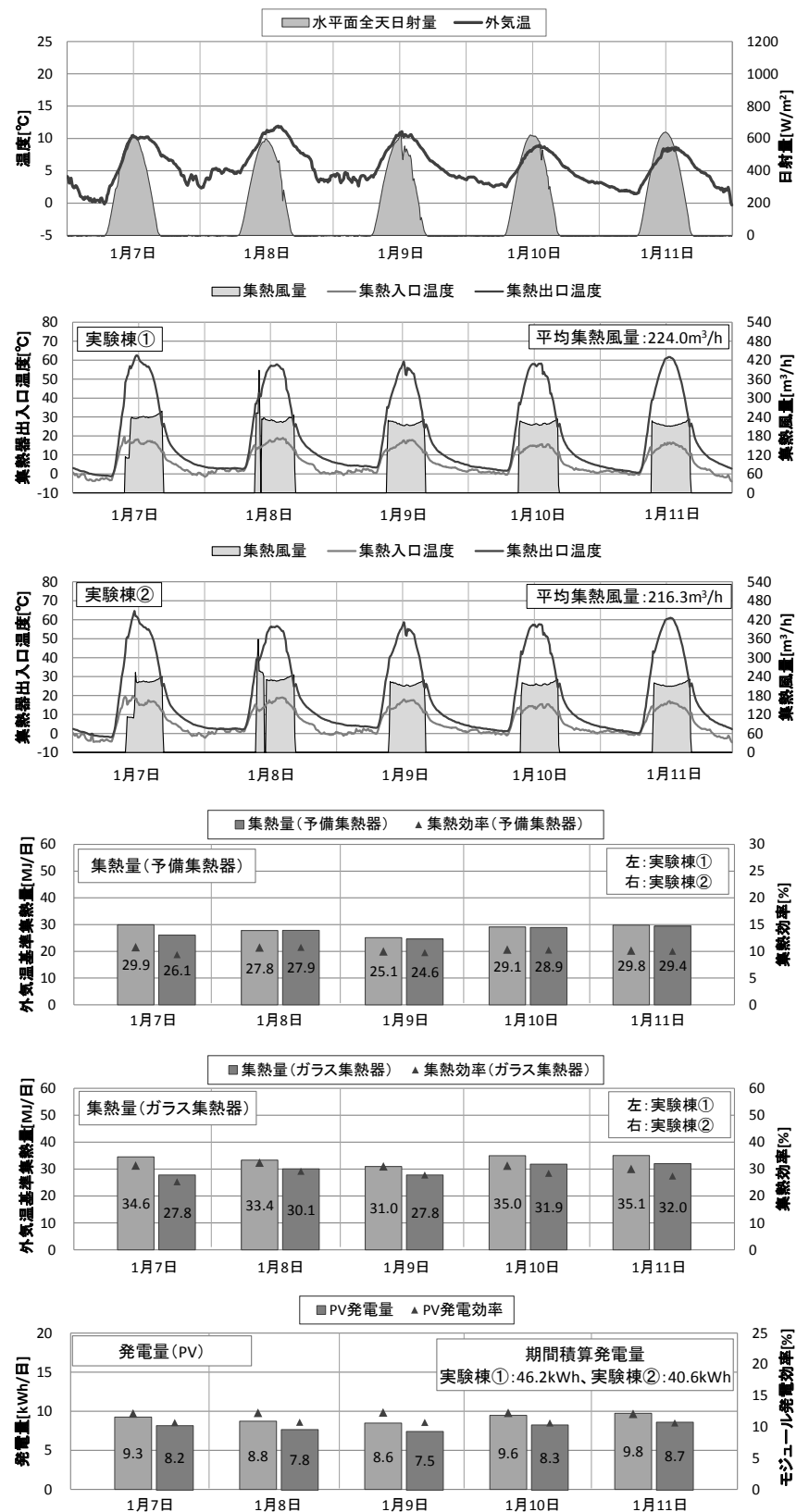

図 17 外気状況、集熱 $\cdot P V$ 発電結果 $(1$ 月 7 日 11 日)

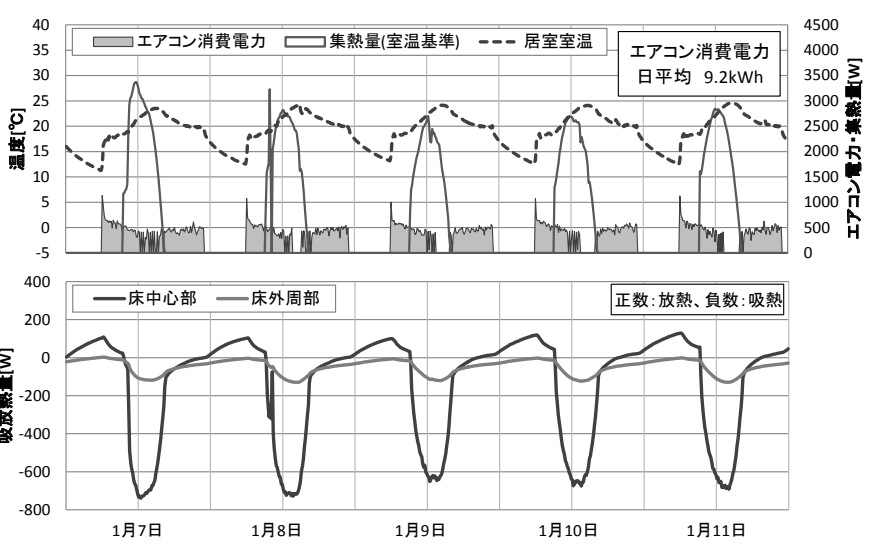

図 18 実験棟(1)の室温、集熱量、エアコン消費電力、基礎吸放熱

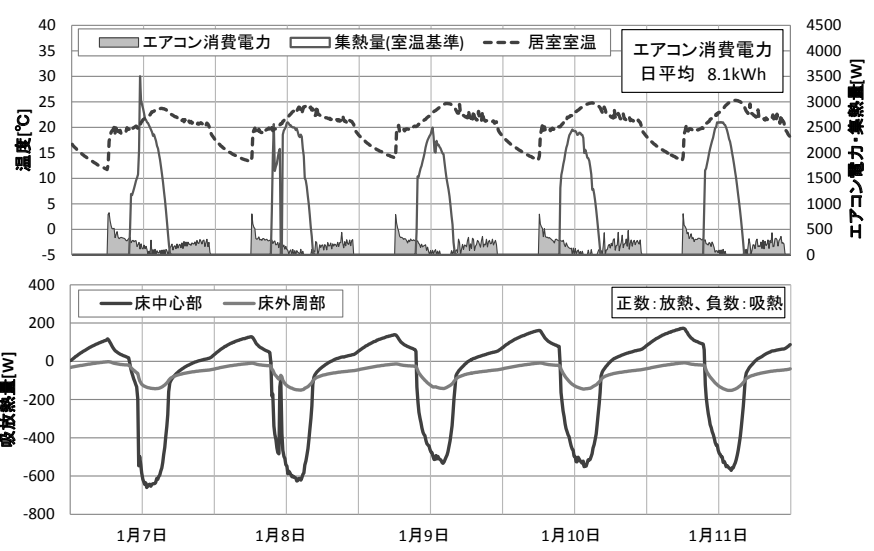

図 19 実験棟(2)の室温、集熱量、エアコン消費電力、基礎吸放熱

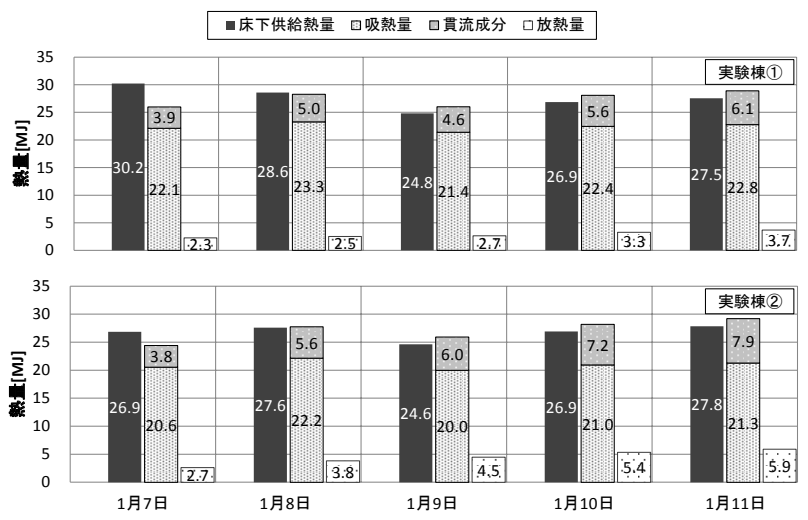

図 20 実験棟(1)と(2)の床下における熱収支

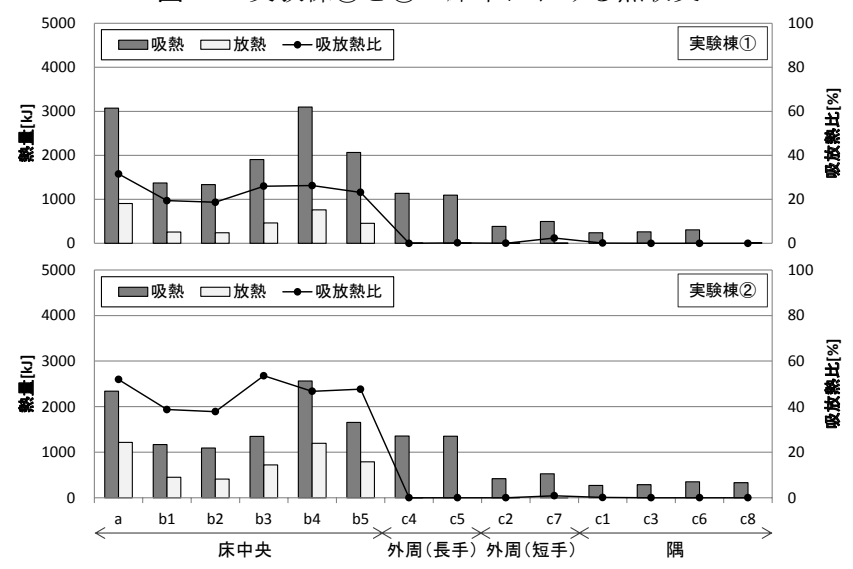

図 21 実験棟 (1) と (2)基礎床中心部と床外周・床隅部での 部位ごとの吸放熱状況 
る居室室温、エアコン消費エネルギー、基礎表面の吸放熱状況の時 系列データを示す。基礎下断熱がない実験棟(1)の場合、基礎下断熱 がある実験棟(2)よ朝立ち上がりのエアコン消費エネルギーが大き く、室温がエアコンの設定温度である $20^{\circ} \mathrm{C}$ 付近まで上がるのにも時 間がかかった。この結果は実験棟(1)と（2)の Q 值の差によるものであ ると考えられる。しかし、基礎コンクリートからの吸放熱比は基礎 下断熱の有無によらず大きく変わらなかった。基礎床部の熱容量に 対して集熱量が小さいため基礎コンクリートへの吸熱量も小さくな り、両者での差がつかなかったものと考えられる。

\section{3 実験 C の結果（集熱 4 列でのシステム運用状況）}

次に、集熱器面積を 4 列（予備集熱器面積 $14.8 \mathrm{~m}^{2}$ 、ガラス集熱器 面積 $5.0 \mathrm{~m}^{2}$ ） と 2 倍にした時の基䃈下断熱の効果とエアコン消費エ ネルギーの違いを評価した。測定期間は 2013 年 1 月 7 日〜 14 日で ある。図 17 に比較的に日射量が安定していた 5 日間の気象条件と 集熱量、集熱効率を示寸。表 6 のように実験における PV 発電効率 は定格システム効率と比べ大きな差はなかった。図 18, 19 のように、 実験棟 (1)の基礎床中心部之基䃈床外周部への期間積算吸熱量は $106.3 \mathrm{MJ}$ (平均集熱風量 $224.0 \mathrm{~m}^{3} / \mathrm{h}$ )、実験棟(2)は $95.6 \mathrm{MJ}$ (平均集 熱風量 $216.3 \mathrm{~m}^{3} / \mathrm{h}$ ) と大きな差はないが、集熱停止時の基礎床中心 部と基礎床外周部からの期間積算放熱量はそれぞれ $14.5 \mathrm{MJ}$ 、 $22.3 \mathrm{MJ}$ となり、基礎下断熱なしの実験棟(1)と比較し、実験棟(2)で の放熱量は約 1.5 倍増加した。図 20 に 1 日ごとの床下供給熱量、 蓄熱体（基礎コンクリート）への吸放熱量、床貫流熱量の熱収支を 示す。図 21 に実験棟(1)と(2)の日平均した基䃈コンクリート床中心 部・床外周部での詳細な吸放熱状況を示す。実験棟(1)基礎への期間 積算放熱量は $106.3 \mathrm{MJ}$ 、放熱量は $18.7 \mathrm{MJ}$ で、吸熱した熱の約 $17.6 \%$ が放熱するが、実験棟(2) 95.6MJ 吸熱して $28.1 \mathrm{MJ}$ 放熱し、約 $29.4 \%$ の吸放熱比となった。集熱実験の精度検討のため、床下供給

表 $6 \mathrm{PV}$ 発電効率 $(1$ 月 7 日 11 日 )

\begin{tabular}{|c|c|c|c|c|}
\hline & & & 実験棟 (1) & 実験棟(2) \\
\hline \multicolumn{3}{|c|}{$\begin{array}{c}\text { モジュール発電効率実験結果 } \\
\text { (定格モジュール発電効率) }\end{array}$} & $\begin{array}{c}12.4 \% \\
(12.8 \%) \\
\end{array}$ & $\begin{array}{c}10.8 \% \\
(11.4 \%) \\
\end{array}$ \\
\hline \multicolumn{3}{|c|}{$\begin{array}{c}\text { パワーコンディショナ変換効率実験結果 } \\
\text { (定格パワーコンディショナ変換効率) }\end{array}$} & $\begin{array}{c}93.2 \% \\
(94.5 \%)\end{array}$ & $\begin{array}{c}95.2 \% \\
(94.5 \%)\end{array}$ \\
\hline \multicolumn{5}{|c|}{ 表 7 実験棟(1)熱量精度検討 } \\
\hline & $\begin{array}{r}\text { 床下供給熱量 } \\
\left(Q_{v d}\right)[\mathrm{MJ}]\end{array}$ & $\begin{array}{c}\text { 床下空間空気の } \\
\text { 保有熱量 } \\
\left(Q_{\text {under }}\right) \text { [MJ] }\end{array}$ & $\begin{array}{c}\text { 床下空間空気の } \\
\text { 保有熱量 } \\
\left(Q_{\text {under }}\right) \text { [MJ] } \\
\end{array}$ & $\begin{array}{c}Q_{\text {under }} \text { と } \\
Q_{\text {under' }} \text { \%差 } \\
\text { [MJ] }\end{array}$ \\
\hline 1月 7 日 & 30.2 & 2.40 & 0.02 & 2.38 \\
\hline 1 月 8 日 & 28.6 & -0.18 & 0.02 & -0.19 \\
\hline 1 月 9 日 & 24.8 & -1.11 & 0.00 & -1.11 \\
\hline 1 月 10 日 & 26.9 & -0.31 & 0.00 & -0.31 \\
\hline 1 月 11 日 & 27.5 & 0.02 & 0.00 & 0.02 \\
\hline \multicolumn{5}{|c|}{ 表 8 実験棟(2)熱量精度検討 } \\
\hline & $\begin{array}{r}\text { 床下供給熱量 } \\
\left(Q_{v d}\right)[\mathrm{MJ}]\end{array}$ & $\begin{array}{c}\text { 床下空間空気の } \\
\text { 保有熱量 } \\
\left(Q_{\text {under }}\right) \text { [MJ] } \\
\end{array}$ & $\begin{array}{c}\text { 床下空間空気の } \\
\text { 保有熱量 } \\
\left(Q_{\text {under }}\right) \text { [MJ] } \\
\end{array}$ & $\begin{array}{c}Q_{\text {under }} \text { と } \\
Q_{\text {under' }} \text { の差 } \\
\text { [MJ] } \\
\end{array}$ \\
\hline 1月 7 日 & 26.9 & -0.08 & 0.03 & -0.11 \\
\hline 1 月 8 日 & 27.6 & 0.58 & 0.02 & 0.56 \\
\hline 1 月 9 日 & 24.6 & 0.55 & 0.00 & 0.55 \\
\hline 1 月 10 日 & 26.9 & 1.65 & 0.00 & 1.64 \\
\hline 1 月 11 日 & 27.8 & 2.27 & 0.00 & 2.26 \\
\hline
\end{tabular}

熱量 $Q_{v d}$ 、床貫流熱量（集熱時： $Q_{f}$ 、非集熱時 : $\left.Q_{f}{ }^{\prime}\right)$ 、蓄熱体の吸 放熱量（吸熱量： $Q_{u f}$ 放熱量 : $\left.Q_{u f}{ }^{\prime}\right)$ から求めた 1 日(0:00 23:59) の床下空間空気の保有熱量 $Q_{u n d e r}$ と床下空間温度測定值からの保有 熱量 Qunder 老比較した。式（6）から求めた床下空間空気の保有熱 量を式 (9)、（10）に示す。本来、式（9）によると Qunder と式（10） による Qunder は一致する。実験結果では、表 7 と 8 のように Qunder と $Q_{\text {under }}$ 'の間に少し差があり、床下空間空気の保有熱量の誤差 （ $Q_{\text {under }}$ と $Q_{\text {under }}$ の差）は計測の誤差や床下空間の隙間風の影響な ぞが考えられるが、床下供給熱量 $Q_{v d}$ に対する $Q_{u n d e r}-Q_{u n d e r}$ は実験 棟(1)で期間平均 $0.6 \%$ 、実験棟(2)で期間平均 $3.7 \%$ とわずかであり、 本実験での床下空間の熱収支評価に十分な精度の計測ができている ことを確認した。

$$
\begin{aligned}
& Q_{u n d e r}=Q_{v d}-Q_{f}-Q_{u f}-Q_{f}{ }^{\prime}+Q_{u f}{ }^{\prime} \\
& Q_{\text {under }}=c \rho \cdot V_{u f} \cdot \Delta T_{u f}
\end{aligned}
$$$$
\cdot \cdot(9)
$$
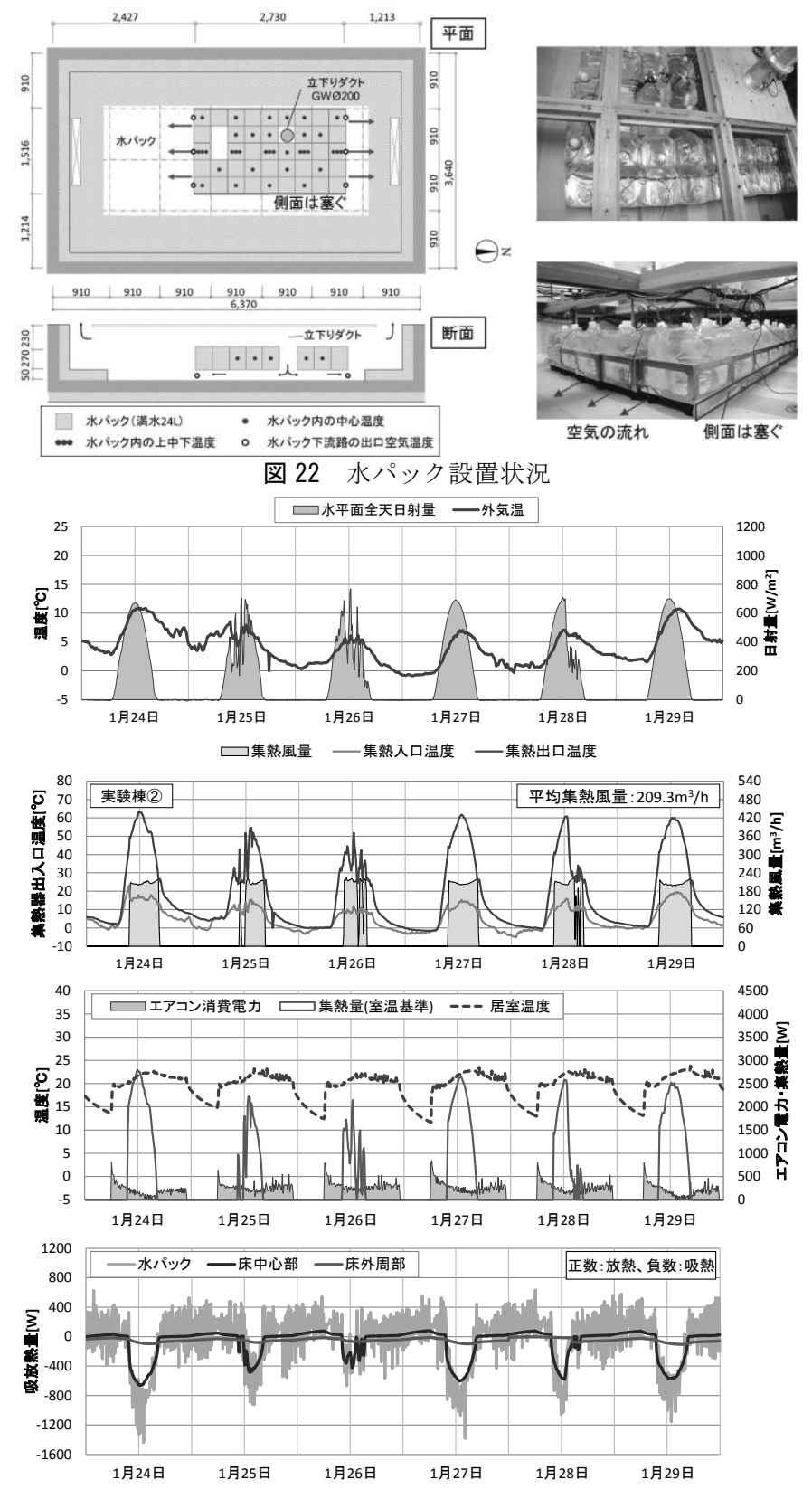

図 23 外気状況、集熱、室温・エアコン消費電力、蓄熱体吸放熱結果 (1月 24 日 29 日) 


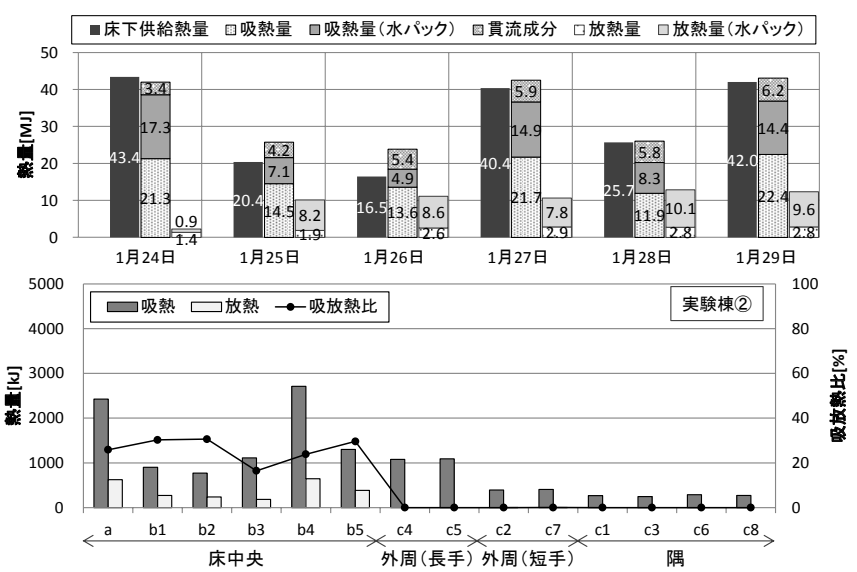

図 24 水パック設置時の基礎床中心部と床外周・床隅部での 部位ごとの吸放熱状況（実験棟(2)）

\section{4 実験 D の結果（付加蓄熱・水パック適用可能性検討）}

さらに、集熱 4 列(予備集熱面積 $14.8 \mathrm{~m}^{2}$ 、ガラス有効集熱面積 $5.0 \mathrm{~m}^{2}$ )、基䃈下断熱有（実験棟(2)）の条件で、床下空間に付加蓄熱 として水パックを設置した時の熱収支や基礎コンクリートの吸放熱 状況を検討した。図 22 のように、床下空間の基䃈から $50 \mathrm{~mm}$ 離し て設置面積 $4.05 \mathrm{~m}^{2}$ 、高さ $270 \mathrm{~mm}$ の中に $1000 \mathrm{~L}$ の水を入れて実験 を進行した。実験期間は 2013 年 1 月 24 日〜29 日である。ここで、 水パック下の隙間に立下りダクトから温風を流すことで、水パック が下から加熱されて、内部の水が対流することとなり、個体の蓄熱 体と比較し、蓄熱体内部の温度むらを抑えることが意図された設置 方法となっている。1000L の水が $1{ }^{\circ} \mathrm{C}$ 温度変化する際に必要な熱量 は約 $4.2 \mathrm{MJ} / \mathrm{K}$ で、基礎コンクリート（基礎床中心部： $2.8 \mathrm{MJ} / \mathrm{K}$ 、 基礎床外周部： $5.1 \mathrm{MJ} / \mathrm{K}$ 、基礎立ち上がり壁：3.4 MJ/K）の約 37\% である。また、この水 $1000 \mathrm{~L}$ の熱容量を居室の延床面積で割った熱 容量は $182 \mathrm{~kJ} / \mathrm{m}^{2} \mathrm{~K}$ となり、文献 9)で示された日射熱利用に必要な 熱容量 $170 \mathrm{~kJ} / \mathrm{m}^{2} \mathrm{~K}$ と同程度となっている。水パック設置時の基礎 コンクリート床中心部・床外周部での吸放熱量は、基礎コンクリー トへの期間積算吸熱量は $107.9 \mathrm{MJ}$ 、放熱量は $14.4 \mathrm{MJ}$ で、吸放熱比 は $13.3 \%$ でった。水パックの温度推移から推定した吸熱量は $66.9 \mathrm{MJ}$ 、放熱量は $45.2 \mathrm{MJ}$ となり、67.6\%の吸放熱比であった。水 パック設置によって基礎からの吸放熱比が減ったのは、集熱運転停 止時に水パックからの放熱で床下空間の温度が上昇して基礎表面と の温度差が小さくなった結果と判断される。また、図 24 のように、 水パックに蓄熱した熱を集熱運転停止時にすぐ放熱できず、集熱量 が小さい日に放熱することを示す。水パックの表面積を増やす、室 内循環運転を行う、その際の循環風量を増やすことなどによって、 床下で吸熱した熱量を非集熱時になるべく放熱し、夜間から翌朝の

表 9 実験棟(2熱量精度検討

\begin{tabular}{|c|c|c|c|c|}
\hline & $\begin{array}{r}\text { 床下供給熱量 } \\
\left(Q_{V d}\right) \text { [MJ] }\end{array}$ & $\begin{array}{c}\text { 床下空間空気の } \\
\text { 保有熱量 } \\
\left(\begin{array}{l}\text { Qunder }) \\
\text { [MJ] }\end{array}\right.\end{array}$ & $\begin{array}{c}\text { 床下空間空気の } \\
\text { 保有熱量 } \\
\left(Q_{\text {under }}\right) \text { [MJ] } \\
\end{array}$ & $\begin{array}{c}Q_{\text {under }} \text { と } \\
Q_{\text {under }} \text { 'の差 } \\
\text { [MJ] }\end{array}$ \\
\hline 1 月 24 日 & 43.4 & 8.06 & 0.03 & 8.03 \\
\hline 1 月 25 日 & 20.4 & -3.15 & -0.01 & -3.14 \\
\hline 1 月 26 日 & 16.5 & -6.68 & -0.01 & -6.67 \\
\hline 1 月 27 日 & 40.4 & 4.19 & 0.02 & 4.17 \\
\hline 1 月 28 日 & 25.7 & 2.50 & 0.13 & 2.37 \\
\hline 1 月 29 日 & 42.0 & 4.08 & 0.02 & 4.06 \\
\hline
\end{tabular}

暖房負荷低減を実現するためのシステムの構築が今後の検討課題と 言える。表 9 の実験の精度検討結果、実験期間中の床下空間空気の 保有熱量の誤差 $Q_{u n d e r}-Q_{u n d e r}$ は床下供給熱量 $Q_{v d}$ に対して、平均約 4.7\%と小さいものであった。

\section{4. まとめ}

空気式集熱システムにおいては、集熱量の確保・蓄熱部での熱損 失低減・蓄熱部位での集熱時の吸熱量向上・蓄熱部位での非集熱時 の放熱量向上が肝要である。本研究では、併設した 3 棟の実験棟に おいて集熱部の性能評価や蓄熱部位での吸放熱特性を評価可能な実 験・計測システムを構築した。本報においては、空気式集熱システ ムを実装し、異なる基礎下断熱仕様とした 2 棟の実験棟を対象とし て、建物全体の熱バランスを把握した上で、システム性能向上のた めの基礎的な検討を行った。結果は、以下のようにまとめられる。

・・ヒーターによる床下加熱実験の結果、基礎下を断熱することで 集熱時の基礎吸熱量が $13.2 \%$ 減り、集熱停止後の基礎コンクリ ートからの放熱量は $12 \%$ 増加していた。これは既往研究のシミ ュレーション結果とも整合しており、今回のような短期間の実 験による評価においても妥当な結果といえる。

・屋外環境下で太陽熱集熱器を使用した際の検討においては、本 研究で対象とした実験棟の集熱器 2 列（合計集熱器面積 $10 \mathrm{~m} 2$, 居室床面積の約 1/2）の場合には、蓄熱部である基礎床部分で の蓄熱が十分に行われず、基礎下断熱有無の差は見られなかっ た。集熱器面積を 4 列に倍増したところ、基礎下断熱の有無に よって、基礎下断熱無しの実験棟 (1) と比較し、基礎下断熱有り の実験棟(2)では基礎床中央部の放熱量が 1.5 倍程度向上した。 基礎床部分での吸熱量は実験棟(2)のほうが小さいことから、居 室床面積に対して現実的な集熱器面積の範囲で効果的に蓄熱 部位での吸放熱を行うには、基礎下断熱を施工したほうが効率 的であるといえる。

・基礎下断熱有りの実験棟(2)において、床下熱容量を増加させる ための工夫として付加蓄熱体の水パック $1000 \mathrm{~L}$ を床下空間に 設置した結果、基礎床部分では吸放熱比（蓄熱部位での吸熱量 に対する放熱量の割合）は $13.3 \%$ と低くなったものの、水パッ ク自体の吸放熱比は $67.6 \%$ と大きかった。床下空間で基礎のみ に蓄熱させる既存システムでは、外気の影響を受けやすい基礎 立ち上がり部や、地中の影響を受けやすい基礎床部分での熱損 失が大きいことが、吸放熱比が小さくなる原因であった。本報 では外部気象に左右されにくい床下空間内部に付加蓄熱体を 効果的に設置することで、昼間に床下空間に蓄熱した熱を非集 熱時にさらに有効利用できる可能性が示された。今回は非集熱 時にハンドリングボックスが運転停止した条件での検討を行 ったが、非集熱時には室内循環運転を行うこと等で、さらに放

熱量は増加するものと予想され、今後の検討課題である。

次報では、本報告ではデータ取得ができていない条件、例えば集 熱量(より高い集熱効率のガラス集熱器への交換)、水パックの容量、 エアコンの設定温度や運転スケジュールの違い、非集熱時に床下に 蓄熱された熱を居室に取り出すための室内循環運転等による暖房負 荷削減効果の実験結果を示すとともに改善システムの提案を行い、 一般住宅における長期間の運用を想定した熱回路網計算等により、 
冬期における集熱量・吸放熱量 ・暖房負荷削減効果等の検討結果を 報告する予定である。

\section{謝辞}

本研究は平成 $23 \sim 25$ 年度 NEDO 太陽熱エネルギー活用型住宅技 術開発助成事業（実施者：OM ソーラー(侏、東京大学、工学院大学） により実施したものである。また、実験に際して OM ソーラー㑣メ ンバーと東京大学前研究室メンバーのご協力を頂きました。ここに 記して感謝の意を表します。

\section{参考文献}

1）田中俊六，鈴木定彦他：屋根一体形太陽熱集熱・大気放射冷却装置に関す る研究, その 5, 各種空気式集熱器の集熱性能, 日本建築学会大会学術講 演梗概集，計画系，pp. 775-776，1983.09

2) 岩田剛, 久保秀人他：ソーラーハウスの性能評価に関寸る研究，その 1 4, 日本建築学会大会学術講演梗概集, D-2, 1996. 07 1997. 07

3）森山実記，中村安弘，小金井真，後藤伴延：太陽熱利用住宅における心゙タ 基礎を利用した蓄熱コンクリートの蓄放熱特性, 空気調和・衛生工学会論文 集(167)，pp.1-10，2011.02

4）赤嶺嘉彦, 桑沢保夫他: 空気集熱ソーラーシステムの省エネルギー効果の 評価に関する研究（第 2 報）暖房集熱時の熱移動と暖房エネルギー削減効 果の計測結果, 空気調和・衛生工学会大会学術講演論文集, 2010.09

5）赤嶺嘉彦, 桑沢保夫他: 空気集熱ソーラーシステムの省エネルギー効果の 評価に関する研究（第 3 報）基礎コンクリートスラブにおける蓄放熱量に 関する計測結果、空気調和・衛生工学会大会学術講演論文集, 2012.09

6）成田有沙，宇田川光弘他：空気式集熱および砕石蓄熱を利用した戸建て住 宅の実測性能、日本建築学会大会学術講演梗概集. D-2, pp. 175-176, 2010. 07

7）井守紀昭，浅野良晴他: 断熱方法の異なる木造実験住宅の長野県における 熱的性能の実測, その 3 , 空気集熱器の効果, 日本建築学会大会学術講演 梗概集. D, pp. 1367-1368，1990.09

8）服部哲幸, 坂本雄三他: 戸建住宅の熱損失係数に関する実用的現場実測法 の開発と実測例、日本建築学会技術報告集, 第 14 巻, 第 28 号, pp. 491-496, 2008. 10

9）準寒冷地版 自立循環型住宅への設計ガイドライン，一般財団法人 建 築環境・省エネルギー機構, 2012

10）田中俊六 : 最新建築環境工学, 井上書院, 1985

注

注 1) 本報で用いた式中の記号を以下に示す。

付表 1

\begin{tabular}{|c|c|c|c|c|c|}
\hline \multicolumn{3}{|r|}{$\begin{array}{l}\text { 計測值 } \\
\end{array}$} & \multicolumn{3}{|r|}{ 計算值 } \\
\hline 記号 & 単位 & 名称 & 記号 & 単位 & 名称 \\
\hline$T_{\text {colout }}$ & ${ }^{\circ} \mathrm{C}$ & 集熱器出口温度 & $Q_{c o l}$ & $\mathrm{~W}$ & 外気温基準集熱量 \\
\hline$T_{o}$ & ${ }^{\circ} \mathrm{C}$ & 外気温 & $Q_{r}$ & $\mathrm{~W}$ & 室温基準集熱量 \\
\hline$T_{r}$ & ${ }^{\circ} \mathrm{C}$ & 居室室温 & $Q_{v}$ & $\mathrm{~W}$ & 換気による熱損失 \\
\hline$T_{u f}$ & ${ }^{\circ} \mathrm{C}$ & 床下空間温度 & $Q_{u f}$ & $\mathrm{~W}$ & 蓄熱体への吸熱量 \\
\hline$T_{h s}$ & ${ }^{\circ} \mathrm{C}$ & 床下蓄熱体表面温度 & $Q_{u f^{\prime}}$ & $\mathrm{W}$ & 蓄熱体からの放熱量 \\
\hline$T_{\text {duct }}$ & ${ }^{\circ} \mathrm{C}$ & 立下り出口温度 & $Q_{v d}$ & $\mathrm{~W}$ & 床下供給熱量 \\
\hline$T_{\text {ufout }}$ & ${ }^{\circ} \mathrm{C}$ & 床吹き出し温度 & $Q_{v u}$ & $\mathrm{~W}$ & 居室供給熱量 \\
\hline$\Delta T$ & ${ }^{\circ} \mathrm{C}$ & 空間の温度変化 & Qunder & $\mathrm{W}$ & 床下空間空気保有熱量 \\
\hline V & $\mathrm{m}^{3 / \mathrm{s}}$ & 風量 & $\eta$ & - & 集熱効率 \\
\hline$I$ & $\mathrm{~W} / \mathrm{m}^{2} \mathrm{~K}$ & 傾斜面日射量 & $\rho$ & $\mathrm{kg} / \mathrm{m}^{3}$ & 空気密度 \\
\hline$F_{h s}$ & $\mathrm{~W} / \mathrm{m}^{2}$ & 表面熱流 & \multicolumn{3}{|r|}{ 設計值 } \\
\hline$Q_{f}$ & $\mathrm{~W}$ & 集熱時の床貫流熱量 & $A_{c o l}$ & $\mathrm{~m}^{2}$ & 集熱器面積 \\
\hline$Q_{f}^{\prime}$ & $\mathrm{W}$ & 非集熱時の床貫流熱量 & $A_{h s}$ & $\mathrm{~m}^{2}$ & 蓄熱体表面積 \\
\hline$Q_{\text {ceil }}$ & $\mathrm{W}$ & 天井面貫流熱量 & Voluf & $\mathrm{m}^{3}$ & 床下体積 \\
\hline$Q_{\text {wall }}$ & $\mathrm{W}$ & 居室壁貫流熱量 & Volr & $\mathrm{m}^{3}$ & 居室体積 \\
\hline$Q_{w i n}$ & W & 空貫流熱量 & $\alpha_{c}$ & $\mathrm{~W} / \mathrm{m}^{2} \mathrm{~K}$ & $\begin{array}{c}\text { 表面対流熱伝達率 (ユル } \\
\text { ゲス式から計算) } 10)\end{array}$ \\
\hline$Q_{g}$ & $\mathrm{~W}$ & 地中、外気への熱損失量 & \multicolumn{3}{|r|}{ 文献值 } \\
\hline & & & $c$ & $\mathrm{~J} / \mathrm{kgK}$ & $\begin{array}{c}\text { 空気比熱 } \\
(1005 \mathrm{~J} / \mathrm{kgK})\end{array}$ \\
\hline
\end{tabular}

※ユルゲス式 ${ }^{10)}$ (普通面）： $a_{c}=5.6+3.9 \cdot v \quad$ 「風速 $(v) \leqq 4.9 \mathrm{~m} / \mathrm{s}$ 」
注 2) 本報で用いた計測点を以下に示す。

付表 2

\begin{tabular}{|c|c|c|c|}
\hline & 項目 & 点数 & センサー \\
\hline \multirow{6}{*}{$\begin{array}{l}\text { 気象 } \\
\text { 観測 }\end{array}$} & 外気温、相対湿度 & 各 1 & $\begin{array}{cl}\text { 温度、湿度計 } \\
\left(-40 \sim 60^{\circ} \mathrm{C} 、 0 \sim 100 \% \mathrm{RH}\right)\end{array}$ \\
\hline & 日射量（水平面） & 1 & $\begin{array}{c}\text { 日射計 } \\
\text { (ISO9060 Second Class) }\end{array}$ \\
\hline & 日射量（傾斜面） & 1 & $\begin{array}{c}\text { 日射計 } \\
\text { (ISO9060 Secondary } \\
\text { standard) } \\
\end{array}$ \\
\hline & 風向、風速 & 1 & $\begin{array}{c}\text { 風向風速計 } \\
\left(0 \sim 40 \mathrm{~m} / \mathrm{s}, 0 \sim 355^{\circ}\right)\end{array}$ \\
\hline & 長波長放射量 & 1 & $\begin{array}{c}\text { 長波長放射計 } \\
\text { (感度 } 42.2 \mathrm{mV} / \mathrm{kW} \cdot \mathrm{m} 2 \text { ) }\end{array}$ \\
\hline & SAT（水平面、傾斜面） & 各 1 & 熱電対 \\
\hline \multirow{4}{*}{$\begin{array}{l}\text { 基礎・ } \\
\text { 床下 } \\
\text { 空間 }\end{array}$} & 表面熱流 & 11 & 小型熱流計 \\
\hline & 表面温度 & 11 & 小型熱流計 \\
\hline & 基礎内部温度 & 36 & シース熱電対 \\
\hline & 空間、表面温度 & 63 & 熱電対 \\
\hline \multirow{4}{*}{ 居室 } & 表面熱流 & 19 & 小型熱流計 \\
\hline & 表面温度 & 19 & 小型熱流計 \\
\hline & 空間、表面温度 & 150 & 熱電対 \\
\hline & グローブ温度 & 5 & 熱電対 \\
\hline \multirow{2}{*}{$\begin{array}{l}\text { 測定 } \\
\text { 器室 } \\
\end{array}$} & 空間 & 1 & 熱電対 \\
\hline & グローブ温度 & 1 & 熱電対 \\
\hline \multirow{3}{*}{ 小屋裏 } & 空間 & 1 & 熱電対 \\
\hline & グローブ温度 & 1 & 熱電対 \\
\hline & 排気チャンバ内 & 1 & 熱電対 \\
\hline \multirow{14}{*}{ 集熱器 } & 出入口温度 & 6 & 熱電対 \\
\hline & PV パネル裏面温度 & 8 & 熱電対 \\
\hline & 通気層空気温度 & 8 & 熱電対 \\
\hline & 棟ダクト温度 & 4 & 熱電対 \\
\hline & ハンドリングダクト温度 & 4 & 熱電対 \\
\hline & 立下りダクト風量 & 1 & 超音波流量計 \\
\hline & 集熱、リターンダクト風量 & 2 & ピトー管方式 \\
\hline & 立下りダクト温度 & 5 & 熱電対 \\
\hline & 太陽光発電 $\quad \mathrm{DC}$ 電圧 & 1 & \multirow{6}{*}{$\begin{array}{c}\text { トランスデューサ、 } \\
\mathrm{CT}+\text { トランスデューサ }\end{array}$} \\
\hline & 太陽光発電 $\mathrm{DC}$ 電流 & 1 & \\
\hline & 太陽光発電 $\mathrm{DC}$ 電力 & 1 & \\
\hline & 太陽光発電 $\mathrm{AC}$ 電圧 & 1 & \\
\hline & 太陽光発電 $\mathrm{AC}$ 電流 & 1 & \\
\hline & 太陽光発電 $\mathrm{AC}$ 電力 & 1 & \\
\hline \multirow{4}{*}{ エアコン } & エアコン吹出温度 & 5 & 熱電対 \\
\hline & エアコン吸込温度 & 3 & 熱電対 \\
\hline & エアコン吸込風速 & 1 & 熱線風速計 \\
\hline & エアコン電源＼cjkstart電圧、電流 & 4 & $\begin{array}{c}\text { トランスデューサ、 } \\
\text { CT+トランスデューサ }\end{array}$ \\
\hline
\end{tabular}

（2013年 6 月10日原稿受理，2013年12月17日採用決定） 